\title{
Validity and reproducibility of a semi-quantitative food-frequency questionnaire for estimating calcium intake in Belgian preschool children
}

\author{
Inge Huybrechts ${ }^{1}$, Dirk De Bacquer ${ }^{1}$, Christophe Matthys ${ }^{1}$, Guy De Backer ${ }^{1}$ and Stefaan De Henauw ${ }^{1,2}$ \\ ${ }^{1}$ Department of Public Health, Faculty of Medicine and Health Sciences, Ghent University, Ghent, Belgium \\ ${ }^{2}$ Department of Health Sciences, Vesalius, Hogeschool Gent, Belgium
}

(Received 28 June 2005 - Revised 16 September 2005 - Accepted 8 November 2005)

\begin{abstract}
Relative validity and reproducibility of a semi-quantitative food-frequency questionnaire (FFQ) for measuring preschool children's usual Ca intake were assessed using parents or guardians as a proxy. Estimated diet records (EDR; $3 \mathrm{~d}$ ) were used as the reference method and reproducibility was measured by repeated FFQ administrations 5 weeks apart. From 2095 preschool children (2.5-6.5 years) randomly selected in Flanders (Flemish region of Belgium), 1052 returned a FFQ and EDR. Stringent exclusion procedures reduced the sample for validity analyses to 509 children. From a separate sample of 244 preschool children, 124 returned two FFQ, of whom sixty were included in the reproducibility analysis. Mean Ca intakes were 838 (SD 305 ) and 777 (SD 296) $\mathrm{mg} / \mathrm{d}$ for EDR and FFQ respectively, indicating a mean difference of 60.9 (SD 294.4) $\mathrm{mg} / \mathrm{d}(P<0 \cdot 001)$. Pearson's correlation was 0.52. Cross-classification analysis of the FFQ and EDR classified $83 \%$ of the subjects in the same or adjacent category and $2.4 \%$ in extreme quartiles. Actual values for surrogate FFQ quartiles showed a progressive increase in Ca intake $(P<0.001)$. The FFQ correctly identified $77 \%$ of the children consuming less Ca than the age-specific RDA $(800 \mathrm{mg} / \mathrm{d})$. Correlation between repeated administrations was 0.79. No significant difference between mean Ca intakes was established by two administrations $(23.8$ (SD 161.2) $\mathrm{mg} / \mathrm{d}$ ). Cross-classification of repeated administrations classified $93.4 \%$ of the subjects in the same or adjacent category and no subjects in extreme categories. This FFQ tended to underestimate preschool children's Ca intake when administered by a proxy. However, it demonstrated good repeatability and fairly good ability to classify subjects into extremes of Ca intake.
\end{abstract}

Calcium: Dietary assessment: Food-frequency questionnaires: Children: Validation

Even though clinical consequences of adverse bone health are predominantly seen in old age, evidence is accumulating that many predisposing factors to osteoporosis arise in childhood (Davies et al. 2005). Bone mineral content at old age is determined by the peak bone mass attained in young adulthood and subsequent adult bone loss (Kalkwarf et al. 2003). While peak bone mass is mainly genetically controlled, $\mathrm{Ca}$ intake during childhood and adolescence is considered to play an important role in bone health (Johnston et al. 1992; Matkovic, 1992). Therefore, interventions designed to maximise bone health should start at an early age.

Since little is known concerning dietary $\mathrm{Ca}$ intakes in young children in Belgium, knowledge about the actual $\mathrm{Ca}$ intake and identification of children with low $\mathrm{Ca}$ intakes should be obtained in order to start goal-oriented interventions. Consequently, there is need for a method of estimating dietary $\mathrm{Ca}$ intake that is practical for large-scale surveys and epidemiological studies in this younger population.

However, accurate assessment of nutrient intakes of freeliving individuals remains a difficult and labour-intensive process. No single assessment method of an individual's usual intake is optimal under all conditions. The choice of method depends, for instance, on the aim of the study, the skills of the study population, the accuracy of the dietary data required and the funds and personnel available (Willett, 1998). One of the most accurate methods to calculate dietary intake is the weighed food record. However, this method is time consuming and generally suitable only for individuals or small groups of cooperative volunteers (Willett, 1998). Routine assessment of diet in a large number of individuals from a range of socioeconomic backgrounds requires a quicker and simpler method for estimating the intake of specific nutrients. Foodfrequency questionnaires (FFQ) are shown to be a practical and efficient approach to assess habitual diet over periods of time (Treiber et al. 1990; Willett, 1998). Although the validity of dietary data collected using FFQ has been studied extensively, as reviewed by Willett (1998), only few studies have assessed the validity and/or repeatability of FFQ in young children, using parents as a proxy (Treiber et al. 1990). Since diet measurements in young children need to rely on parents or other caregivers to report the child's food habits, one can question the ability of parents to accurately report their child's diet when other caregivers also feed the child (for example, guardians at school).

In an attempt to answer these questions, we conducted a validation study of a semi-quantitative FFQ for measuring $\mathrm{Ca}$ intake in preschool children, using parents or any other educator substantially responsible for the child's food supply 
as a proxy. The development and validation of this newly developed FFQ was done in the context of a large-scale epidemiological study investigating nutrition habits of preschool children in Flanders (Flemish region of Belgium). In the present paper we describe the results of the validation and repeatability study of this FFQ for measuring $\mathrm{Ca}$ intakes in preschool children.

\section{Methods}

\section{Study population}

Participants in the validation study were part of a pool of children included in a large-scale epidemiological study investigating nutrition habits of preschool children in Flanders (2.5-6.5 years old). The sampling design included a combination of stratification and multistage sampling techniques. Schools, used as primary sampling units, were randomly selected from a database of all nursery schools from the Flemish Ministry for Education and were stratified over the different provinces in Flanders. Within every school that participated in the study, for each age group, only one class was selected as the secondary sampling unit. Children were excluded from the study when:

(a) they were staying in an institution (for example, a hospital school), where the food was provided by the institution;

(b) they were not attending school during the whole period of the fieldwork;

(c) they were living abroad;

(d) when both their parents did not speak Dutch.

Out of a total number of fifty nursery schools participating in the dietary survey in preschool children, forty-three were included in the validation study, while seven schools refused to distribute food diaries (reference method; described later), as this was considered too burdening for the children and their parents. Within these forty-three schools, a total of 2095 children were invited in this validation study and were asked to complete a FFQ, a $3 \mathrm{~d}$ estimated diet record (EDR) and a general questionnaire. A total of 1579 FFQ and 1052 EDR were collected by the end of the fieldwork.

For the reproducibility study, 244 children were selected in a separate sample of three nursery schools in the province of East-Flanders. In total, 169 subjects returned a FFQ during the first administration, of which 124 returned a second FFQ too.

\section{Food-frequency questionnaire}

The semi-quantitative FFQ contained questions on the average consumption of forty-seven food items during the past 1 year (see Appendix). Parents were asked to indicate their answers in a list of frequencies: every day; $5-6 \mathrm{~d} /$ week; $2-4 \mathrm{~d} /$ week; $1 \mathrm{~d} /$ week; $1-3 \mathrm{~d} /$ month; never or less than $1 \mathrm{~d} /$ month. The FFQ also contained three or four daily portion size categories per food item and a list of common standard measures as examples. For the solid food groups, only three portion size categories were included, as the daily portion sizes of preschool children are too small to divide into four categories. Liquid products are consumed in higher quantities, which makes it feasible to create four portion size categories. Parents were asked to indicate the portion size category that best fits the daily portion of their child. The food categories in the FFQ were based on the classification system, described in the Flemish Food guide (so-called food triangle) (Flemish Institute for Health Promotion, 2004). As a primary objective of this investigation was to estimate the $\mathrm{Ca}$ intake of Flemish preschool children, food or groups with a high $\mathrm{Ca}$ content and part of the typical Flemish diet or with a moderate $\mathrm{Ca}$ content but commonly eaten by children and adolescents were included in the FFQ (Matthys et al. 2003). Furthermore, the FFQ included fifteen additional questions inquiring more detailed information about some product groups (see Appendix). Other validated Ca questionnaires (Wilson \& Horwath, 1996; Taylor \& Goulding, 1998; Montomoli et al. 2002) were used as basic materials for the conceptualisation of our final FFQ.

$\mathrm{Ca}$ intakes were computed by multiplying the frequency of consumption of each food group by the mean Ca content (calculated for the food group concerned) per $100 \mathrm{~g}$ product and by the specified portion.

\section{Estimated diet record - reference method}

In the present study the EDR was chosen as the reference method. Parents were asked to collect structured EDR over three consecutive days. In these EDR, days were subdivided into six eating occasions, namely, breakfast, morning snacks, lunch, afternoon snacks, dinner and evening snacks. Detailed information on the type (including brand names) and portion size of the foods consumed was collected using an open entry format. On a separate sheet, recipes could be described in more detail. After collection, the EDR were coded and entered in a 'Diet Entry and Storage' program (BECEL Nutrient Calculation Program; Nederlandse Unilever Bedrijven B.V. Rotterdam, The Netherlands). The program itself calculated the daily nutrient intake for twenty-six nutrients and stored the foods and portion sizes eaten per meal per $\mathrm{d}$. The food list and food composition data for these programs were based on the following tables: Belgian food composition table NUBEL (2004); Dutch food composition database NEVO (NEVO Foundation, 2001); food composition table of the Belgian Institute Paul Lambin (2004); McCance and Widdowson's UK food composition table (Food Standards Agency, 2002).

\section{General questionnaire}

In order to evaluate possible determinants for food consumption habits, a general questionnaire, registering additive information about the child (for example, male or female, physical activity level, consumption of lunch at school), its parents (for example, age, parental education levels, birth countries) and the family composition was collected in addition. In this general questionnaire, the parents were also asked to report the weight and height of their child. Children's BMI was calculated, using these parentally reported weight and height values. Subsequently, subjects were classified as being overweight or obese, applying the BMI cut-off values for children from Cole et al. (2000). 


\section{Data collection}

The directors of the schools and/or the teachers of the classes that participated in the study were given detailed information and instructions about the study. The teachers were asked to hand out the FFQ to the parents of the children. The completed questionnaires were handed in at school again, in a sealed envelope. Schools participating in the validation study distributed the food diaries 1 week after the collection of the FFQ. To ensure that all the days of the week would be registered equally, the research team determined beforehand the days that the parents had to register. Schools participating in the reproducibility study distributed a second FFQ 5 weeks after the collection of the first FFQ. In the FFQ and the food diaries, detailed instructions were given for the parents. The FFQ were anonymous and the parents had to sign an informed consent to take part in the study.

The fieldwork of the validation and the reproducibility study was carried out in the winter of $2002-3$. The ethical committee of the Ghent University Hospital (Belgium) granted ethical approval for the study.

\section{Statistical analysis}

Only good-quality food diaries (EDR), including three completed record days and containing sufficiently detailed descriptions of the food products and portion sizes consumed, were included in the analysis. Two dietitians, with longstanding experience in nutritional epidemiological fieldwork, carried out the exclusion procedure of the EDR. As a cross-check, average energy intake and nutrient intakes were calculated as the mean of the three recorded days. Diaries that produced very high or very low estimates of intake for some nutrients (for example, energy, $\mathrm{Ca}$ and $\mathrm{Fe}$ ) were rechecked by the dietitians. This amounted to $5 \%$ of the diaries. In this cross-check, only diaries having extremely low estimates for some nutrient intakes, explained by an exceptional day (such as sickness of the child), have been excluded from the study.

In total, the food diaries of 356 children needed to be excluded. Therefore, the total number of diaries being of use for the validation study was reduced from 1052 to 696 (Fig. 1).

In the validity study, the FFQ of seventy-two children had to be excluded completely, since less than half of the questions had been answered. Besides, an individual's habitual daily $\mathrm{Ca}$ intake could only be computed when the respondent filled in a frequency and portion size for all the forty-seven food groups included in the FFQ. For 447 of the remaining FFQ, no daily $\mathrm{Ca}$ intake could be calculated, since at least one frequency or portion size was missing.

The total number of FFQ being of use for the validity analysis of daily $\mathrm{Ca}$ intake was reduced from 1579 to 1065 and for the reproducibility study from 124 to sixty FFQ.

Combining the FFQ with the $3 \mathrm{~d}$ EDR, only 509 children remained of use for the validity analysis.

The Statistical Package for the Social Sciences for Windows version 12 (SPSS Inc., Chicago, IL, USA) was used to carry out all statistical analyses. Unless reported differently, a $P$ value of 0.05 was used as the threshold for significance. Two-sided significance levels were quoted. Tests for normal-

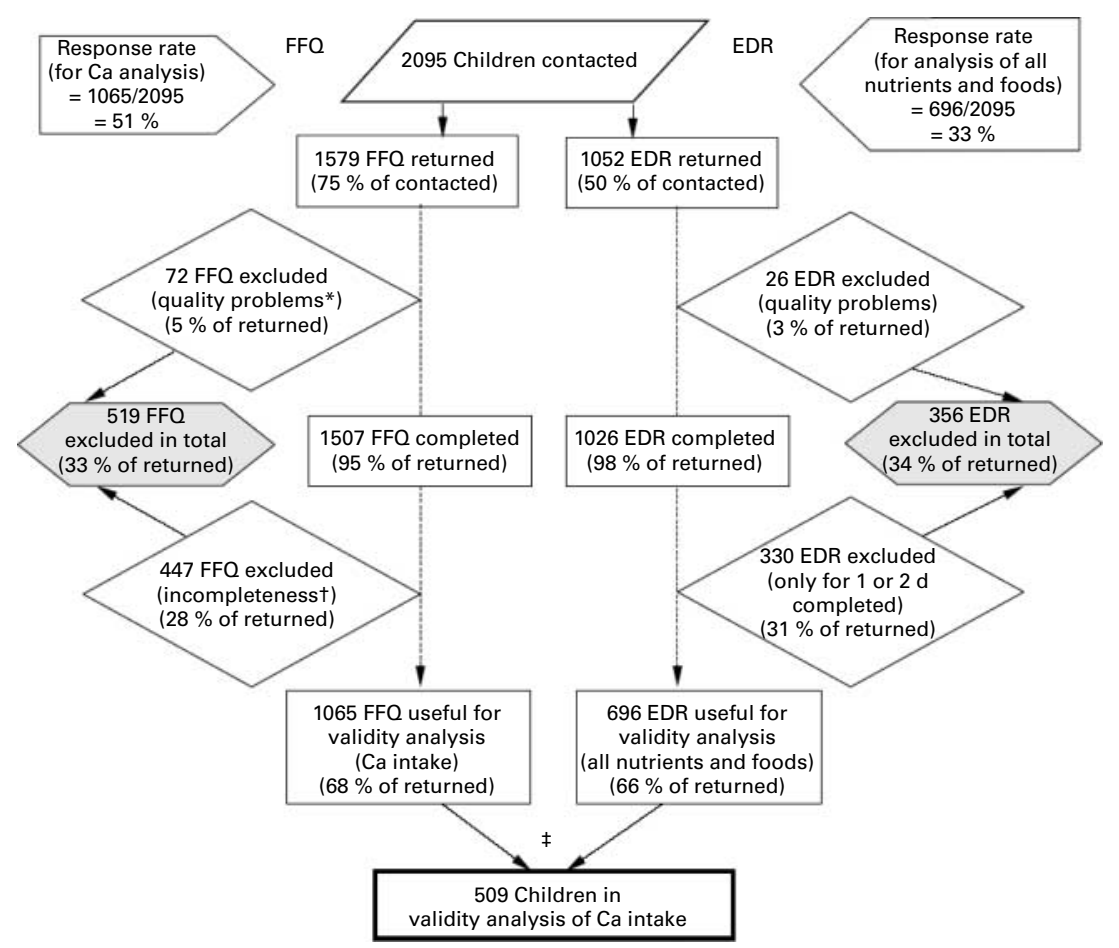

Fig. 1. Response rates over the course of the study. FFQ, food-frequency questionnaire; EDR, estimated diet record. * Less than half of the questions had been answered, so excluded from all of the analysis. † One or few missing values for frequency or portion size questions in the FFQ. $\ddagger$ One hundred and eighty-seven children could not be included in the validity analysis of Ca intake, since one (or a few) of the forty-seven frequency or portion size options were missing. However, these children could be used for other objectives (for example, intake of a specific food group). For details of subjects and procedures, see p. 803 
ity were performed using the Kolmogorov-Smirnov test. Ca intake distributions were for both methods normally distributed. ANOVA was used to compare several group means.

The mean $\mathrm{Ca}$ intakes from each day of the week recorded were compared in order to determine whether it was necessary to adjust for days of the week recorded.

Misreporting of the EDR was evaluated by comparing the mean observed daily energy intake (OEI) derived from the EDR with the Belgian estimated average requirement (EAR) for each child ( $\mathrm{kJ} / \mathrm{kg}$ per d), taking into account the age, sex and weight of the child (Commission of the European Communities, 1993; Nationale Raad voor de Voeding, 2005). In the present study, a child was considered a potential under-reporter if EAR exceeded OEI by more than $1344 \mathrm{~kJ}$, whereas if the reverse was true, the child was considered a possible over-reporter. This value $(1344 \mathrm{~kJ})$ represents $22.2 \%$ of the overall mean value as suggested by Davies et al. (1994) in an analysis of energy intakes related to energy expenditure.

Using the equations for calculating BMR from body weight given in the 1985 FAO, WHO and United Nations University report on protein and energy requirements (Anonymous, 1985; Schofield, 1985), cut-off values for OEI:BMR were used in addition. Torun et al. (1996) considered values of OEI:BMR lower than two times the CV below the PAL corresponding to light habitual activity, or higher than two times the CV above the PAL for heavy habitual activity, unlikely to represent the usual intake of healthy children. For children (boys and girls) between 1 and 5 years old, the values 1.28 and 1.79 were estimated as provisional cut-offs for respectively under- and over-reporting, while the cut-offs for children aged $6-18$ years old were respectively 1.39 and 2.24 for boys and 1.30 and 2.10 for girls (Torun et al. 1996).

In order to estimate potential selection bias, due to elimination of incomplete questionnaires or diaries, characteristics concerning children who were excluded from the analysis were compared with those of the children included in the analysis. Depending on the variable type, independent samples $t$ tests or cross-tabulations with $\chi^{2}$ or Fisher's exact tests were used.

In the validity study, the difference between mean $\mathrm{Ca}$ intakes was tested using the paired $t$ test and the association between the two methods for $\mathrm{Ca}$ intake was described using Pearson's correlation coefficient. In addition, the correlation coefficient, comparing the FFQ with the EDR for Ca intake, was corrected for within-individual variation. Agreement between the EDR and the FFQ at an individual level was assessed using mean difference and standard deviation of the difference, which was visually shown in a Bland and Altman plot (Bland \& Altman, 1986). Individual results for Ca intake estimated by the EDR and the FFQ were classified into quartiles to assess the questionnaire's ability to assign individuals to the same quartile of intake as the EDR (Willett, 1998). The percentage classified into the correct or adjacent quartile and the percentage grossly misclassified (lowest quartile for one method and highest quartile for the other) were calculated. Agreement has also been assessed using the weighted $\kappa$ statistic, calculated with a linear set of weights (Altman, 1991). To assess the measurement error of the FFQ, 'actual values for surrogate categories' were calculated (Willett, 1998).
Specificity was defined as the proportion of those with a daily $\mathrm{Ca}$ intake below $800 \mathrm{mg}$ on the basis of the EDR who also fell below $800 \mathrm{mg}$ on the FFQ. Sensitivity was the proportion of those with a daily $\mathrm{Ca}$ intake above $800 \mathrm{mg}$ on the basis of the EDR who also fell above $800 \mathrm{mg}$ on the FFQ. The predictive value was the proportion of those who fell below $800 \mathrm{mg}$ on the FFQ whose actual recorded intake was less than $800 \mathrm{mg} \mathrm{Ca} / \mathrm{d}$.

For the reproducibility of the FFQ in measuring daily $\mathrm{Ca}$ intakes, paired $t$ test, Pearson correlation coefficient, mean difference and standard deviation of the difference, weighted $\kappa$ and cross-classification analysis for $\mathrm{Ca}$ intakes between the first and second FFQ administration were measured.

Analysis of covariance was used to determine and control for potential confounding factors in determining validity and/or reproducibility of a FFQ. The variables used in these covariance analyses derived from the general questionnaire.

\section{Results}

\section{Validation study}

Subjects included in the validation study for Ca intake ( $n$ 509) had a mean age of 4.5 (SD 1 ; range $2.5-6.5$ ) years. Forty-four $(9.8 \%)$ children were classified as overweight; twelve of these $(2.7 \%)$ were obese. In total, $49.8 \%$ of the children were boys and $50.2 \%$ were girls. Since the recommendations are identical for both sexes and there were no significant sex differences in $\mathrm{Ca}$ intake, results for boys and girls were analysed together.

Within the EDR, used in the validation study, $28.6 \%$ of the registered days were weekend days. When mean or median estimated $\mathrm{Ca}$ intakes on the different days of the week were compared, no significant differences between the different days of the week were found $(P=0 \cdot 18)$. Therefore, it was considered unnecessary to adjust for days of the week recorded.

The mean OEI (6053 (SD 1204.05) kJ) measured with the $3 \mathrm{~d}$ EDR was significantly lower than the mean daily energy required $(6525(\mathrm{SD} 1204.51) \mathrm{kJ})(P<0 \cdot 001)$ and the percentage of under- and over-reporters was respectively 23.2 and 9.8 when compared with these requirements. Although, when using the alternative method, with age- and sex-specific cut-off values for OEI:BMR, the percentage classified as under-reporters was 14.4 , while the number of over-reporters was $28.5 \%$.

Children who had been excluded because of incomplete FFQ data did not differ significantly in mean Ca and energy intake calculated from the EDR, in comparison with the other children who were included in the analyses. In an additional check for selection bias, these two groups of subjects have been compared for a variety of socio-demographic parameters. No significant differences were found for any of the parameters derived from the general questionnaire.

Mean daily Ca intakes were 838 (SD 305) and $777 \mathrm{mg} / \mathrm{d}$ for the $3 \mathrm{~d}$ EDR and FFQ respectively $(P<0 \cdot 001)$. The mean difference in $\mathrm{Ca}$ intake between the two methods was 60.9 (SD 294.4; $95 \%$ CI 35.2, 86.5) $\mathrm{mg} / \mathrm{d}$, demonstrating that the FFQ underestimated $\mathrm{Ca}$ intakes in comparison with the EDR and assessed $\mathrm{Ca}$ intakes from $528 \mathrm{mg} / \mathrm{d}$ above to $650 \mathrm{mg} / \mathrm{d}$ below the EDR (Bland \& Altman, 1986). This is graphically shown in a Bland \& Altman plot (Fig. 2). A visual inspection 


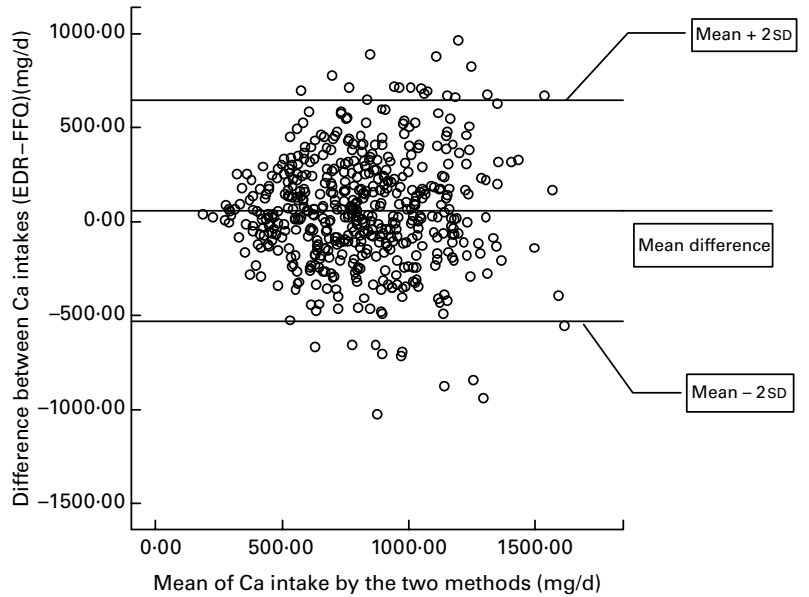

Fig. 2. Differences between the mean $\mathrm{Ca}$ intake for the $3 \mathrm{~d}$ estimated diet record (EDR) and the food-frequency questionnaire (FFQ) in the validation analyses. For details of subjects and procedures, see p. 803.

of this graph shows higher differences for higher mean $\mathrm{Ca}$ intakes (divergence).

The Pearson correlation coefficient between the $3 \mathrm{~d}$ EDR and the FFQ for daily $\mathrm{Ca}$ intake was $0 \cdot 52$. Using the ratio of within- and between-individual variances for the EDR (0.90) or the intraclass correlations $(0 \cdot 53)$, the correlation coefficient, corrected for intra-variability was 0.59 (Willett, 1998).

Cross-classification analysis indicated that twelve subjects $(2.4 \%)$ were grossly misclassified, while 213 subjects $(42 \%)$ were classified correctly and 423 participants $(83 \%)$ were classified correctly or in the adjacent category (Table 1). The weighted $\kappa$ statistic was 0.38 (95\% CI $0.34,0.42)$.

Actual values for surrogate FFQ quartiles showed a progressive increase in $\mathrm{Ca}$ intake between the first and fourth quartile (Table 2) with statistically significant differences in mean $\mathrm{Ca}$ intakes between the different quartiles $(P<0 \cdot 001)$.

The specificity and sensitivity of the Ca FFQ, for indicating children with lower and higher $\mathrm{Ca}$ intakes than the recommended daily intake of $800 \mathrm{mg}$, were 77 and $62 \%$ respectively. The actual numbers of children falling in these categories are given in Table 3 . The specificity and sensitivity errors were 11 and $20 \%$ respectively. The proportion of subjects with a FFQ intake below $800 \mathrm{mg}$ who also had a recorded intake below $800 \mathrm{mg}$ (predictive value) was $64 \%$.

\section{Reproducibility study}

Subjects included in the reproducibility study for $\mathrm{Ca}$ intake ( $n$ 60) had a mean age of 4 (SD 1; range 2.5-6.5) years. Only two children were classified as overweight; one of these was obese.

Mean daily Ca intakes were 774 (SD 252) and 751 (SD 255) $\mathrm{mg}$ for the first and second administration respectively and were not significantly different $(P=0 \cdot 26)$. The mean difference in $\mathrm{Ca}$ intake between the two administrations was 23.8 (SD 161.2; $95 \%$ CI 17.8, 65.5) $\mathrm{mg} / \mathrm{d}$, demonstrating that the first FFQ could estimate Ca intakes from $346 \mathrm{mg} / \mathrm{d}$ above to $299 \mathrm{mg} / \mathrm{d}$ below the second FFQ (Bland \& Altman, 1986). This is graphically shown in a Bland \& Altman plot (Fig. 3).
The Pearson correlation coefficient between the $\mathrm{Ca}$ intakes from the first and second FFQ registration is 0.80.

Cross-classification analysis indicated that no subjects were grossly misclassified, while thirty-four $(56.7 \%)$ of the participants were classified correctly and fifty-six (93.4\%) subjects were classified correctly or in the adjacent category. The weighted $\kappa$ statistic was $0.60(95 \%$ CI $0.49,0.71)$.

No significant confounding factors for relative validity and reproducibility of the FFQ were determined in the covariance analysis. Also for children taking lunch at school, the analysis did not differ significantly from children taking lunch at home.

\section{Discussion}

\section{Principal findings}

When registered by a proxy, our semi-quantitative FFQ tended to underestimate actual daily $\mathrm{Ca}$ intakes in preschool children, but demonstrated a fairly good ability to classify subjects into extremes of $\mathrm{Ca}$ intake. Besides, the repeatability of this FFQ for measuring $\mathrm{Ca}$ intake in preschool children was good.

Validity study. Based on the comparison of means, the FFQ underestimated the mean $\mathrm{Ca}$ intake measured by the EDR. Since our FFQ was not designed to estimate energy intake, it was not possible to determine whether this was due to under-reporting. These findings of underestimation of mean daily $\mathrm{Ca}$ intake measured with a FFQ is in contrast to the findings of a previous study, which reported overestimates of actual $\mathrm{Ca}$ intakes in young children (3 to 6 years of age ( $n$ 67)) (Taylor \& Goulding, 1998).

The Bland \& Altman plot showed large standard deviations of the differences between intakes assessed by the two methods, which indicated limited use of the FFQ to estimate $\mathrm{Ca}$ intakes for individuals. However, it is not necessary for the assessment tool to accurately estimate absolute intakes of individuals in order to be useful in an epidemiological setting where extremes of intake are of primary interest. The observed divergence in this plot suggests a greater difficulty in estimating usual dietary $\mathrm{Ca}$ intakes with higher mean $\mathrm{Ca}$ intakes.

Brunner et al. (2001) suggested that correlations between FFQ and weighed records of 'about 0.5 for most nutrients' are 'good evidence that the FFQ has the ability to rank individuals'. Since the correlation coefficient achieved in the present study was 0.52 , we concluded that this parentally reported FFQ showed good ranking ability according to $\mathrm{Ca}$ intakes in preschool children.

Cross-classification analysis demonstrated that the FFQ classified $83 \%$ of the subjects within one quartile of the EDR and $2.4 \%$ of the participants in the extreme quartiles.

These results compare well with results obtained by other researchers who have used this method of analysis for $\mathrm{Ca}$ intakes and are significantly higher than the expected $62.5 \%$ correctly classified to within one quartile due to chance alone (Wilson \& Horwath, 1996; Taylor \& Goulding, 1998; Wilson \& Lewis, 2004).

Since the actual values for surrogate FFQ categories showed the expected significant stepwise increase of $\mathrm{Ca}$ intake between the first and fourth quartile, we concluded that the FFQ could reliably distinguish extremes of $\mathrm{Ca}$ intakes. 
Table 1. Cross-classification analysis for calcium intake from the $3 \mathrm{~d}$ estimated diet record (EDR) and the calcium food-frequency questionnaire (FFQ)(Number of subjects in each category)

\begin{tabular}{lrrrrrrr}
\hline \multicolumn{7}{c}{$\begin{array}{c}\text { Quartiles of daily Ca intake } \\
\text { (EDR) }\end{array}$} & \multicolumn{3}{c}{} \\
\cline { 2 - 4 } Quartiles of daily Ca intake (FFQ) & Q1 & Q2 & Q3 & Q4 & Total & Agreement of quartile categorisation (\%) \\
\hline Q1 & 69 & 36 & 17 & 5 & 127 & $54 \cdot 3$ \\
Q2 & 34 & 35 & 37 & 22 & 128 & $27 \cdot 3$ \\
Q3 & 17 & 39 & 40 & 31 & 127 & 31.5 \\
Q4 & 7 & 17 & 34 & 69 & 127 & 54.3 \\
Total & 127 & 127 & 128 & 127 & 509 & \\
\hline
\end{tabular}

For details of subjects and procedures, see p. 803.

Reporting the identification of actual daily intakes less than the RDA of $800 \mathrm{mg}$, the present study shows that $77 \%$ of the children would be correctly identified. If the Ca FFQ was used to guide intervention efforts, using the RDA as reference value, the specificity error would indicate that $11 \%$ of all the children would lose the possibility of receiving a required intervention, while the sensitivity error would specify that $20 \%$ of the children would be provided with an unneeded intervention. Wilson \& Horwath (1996) showed similar results for the sensitivity and specificity analysis of their short FFQ for assessing dietary $\mathrm{Ca}$ intake in women. However, Taylor \& Goulding (1998) found higher specificity error and lower sensitivity error for their short FFQ to assess $\mathrm{Ca}$ intake in children aged 3 to 6 years old.

Reproducibility study. In reproducibility studies the coefficients of correlation have generally ranged from 0.5 to 0.7 (Willett, 1998). The correlation coefficient obtained by Treiber et al. (1990) for 1 week test-retest reliability of parentally reported FFQ for measuring preschool children's Ca intakes was 0.68 . In the present study, the coefficient of correlation between the first and second administration was $0 \cdot 80$. This high correlation between the repeated administrations indicates that the random response error, sometimes due to lack of interest or motivation of the respondent or lack of clarity of the questionnaire, is rather small.

\section{Methodological issues}

Validity study. The EDR was chosen as the reference method because of its high level of accuracy when validated for assessing dietary intake in infants and children (Lanigan et al. 2001).
Moreover, the measurement errors of the EDR and the FFQ are highly independent, since unlike the FFQ method the EDR does not depend on memory, is open-ended, and involves direct estimation of portion size (Cade et al. 2002). However, like any dietary assessment methodology, the EDR is prone to a degree of misreporting. Therefore, we estimated the degree of under- and/or over-reporting when using the EDR. The levels of under- and/or over-reporting found were highly dependent on the method used. This made it very difficult to draw any conclusions about the real level of misreporting. Nevertheless, the number of under-reporters was much higher when evaluating against the EAR, compared with evaluation against BMR. A possible reason why the EAR is much higher than the recorded energy intake might be that children of today are less active than in the past, when EAR were calculated (Commission of the European Communities, 1993). When comparing OEI against BMR, the percentage of children over-reporting was higher than the percentage under-reporting energy intakes. Torun et al. (1996) also concluded that OEI tend to overestimate the requirements when compared with total energy expenditure and heart-rate monitoring for children under 8-10 years old. A possible explanation therefore might be that parents tend to overestimate their children's portion sizes due to confusion with their own habitual portion sizes. It should be noted that in addition to the credibility of food intake reports, assessment of OEI can be distorted by the use of inadequate food composition tables, while assessment of BMR can be distorted by the use of estimated (parentally reported) weight values. Given these diverging results between the two methods used, no subjects have been excluded on the basis of under- or over-reporting.

Table 2. Use of actual values for surrogate categories to compare the calcium intake (mg/d) of the food-frequency questionnaire (FFQ) with the 3 d estimated diet record (EDR)

(Mean values and standard deviations)

\begin{tabular}{|c|c|c|c|c|c|c|c|c|c|}
\hline & \multicolumn{8}{|c|}{ Ca intake* } & \multirow[b]{3}{*}{$P$} \\
\hline & \multicolumn{2}{|c|}{ Q1 } & \multicolumn{2}{|c|}{ Q2 } & \multicolumn{2}{|c|}{ Q3 } & \multicolumn{2}{|c|}{ Q4 } & \\
\hline & Mean & SD & Mean & SD & Mean & SD & Mean & SD & \\
\hline $3 \mathrm{~d}$ EDR & 466 & 101.5 & 720 & $64 \cdot 2$ & 922 & 65.5 & 1243 & $171 \cdot 1$ & NA \\
\hline $\mathrm{FFQ}$ & 604 & $224 \cdot 7$ & 812 & $269 \cdot 7$ & 883 & 271.0 & 1053 & 269.5 & $<0.001$ \\
\hline
\end{tabular}

NA, not applicable.

*'True mean values' based on the 3 d EDR were assigned to the categories defined by the surrogate method (FFQ) and compared using ANOVA.

For details of subjects and procedures, see p. 803. 
Table 3. Sensitivity and specificity analysis for daily calcium intake estimated from the food-frequency questionnaire (FFQ)* (Number of subjects in each category)

\begin{tabular}{lccc}
\hline & \multicolumn{2}{c}{ Daily Ca intake (EDR) } \\
\cline { 2 - 3 } Daily Ca intake (FFQ) & $<800 \mathrm{mg}$ & $\geq 800 \mathrm{mg}$ & Total \\
\hline$<800 \mathrm{mg}$ & 183 & 103 & 286 \\
$\geq 800 \mathrm{mg}$ & 54 & 169 & 223 \\
Total & 237 & 272 & 509 \\
\hline
\end{tabular}

EDR, estimated diet record.

* Sensitivity is the proportion of those with a daily Ca intake $\geq 800 \mathrm{mg}$ on the basis of the $3 \mathrm{~d}$ EDR who also fell $\geq 800 \mathrm{mg}$ on the FFQ; specificity is the proportion of those with a daily Ca intake $<800 \mathrm{mg}$ on the basis of the $3 \mathrm{~d}$ EDR who also fell $<800 \mathrm{mg}$ on the FFQ.

For details of subjects and procedures, see p. 803.

Even though many recording days (replicates) should give a better estimate of the habitual intake, the problems with long recording periods are declining accuracy of recording with increasing fatigue and boredom, and potential alterations to dietary habits (Gibson, 1987). Taking into account our low ratio of within- and between-individual variances for the EDR (0.90) and according to the methods described by Nelson and colleagues only two replicates should be sufficient to rank our preschool children according to $\mathrm{Ca}$ intakes with good accuracy ( $r$ 0.8) (Nelson et al. 1989; Palaniappan et al. 2003). Also Rosner \& Willett suggested that it is usually optimal to obtain no more than two replicates per individual if the intraclass correlation is greater than or equal to 0.5 (Rosner \& Willett, 1988; Willett, 1998). Since the intraclass correlation for $\mathrm{Ca}$ intakes in the present study is more than 0.5 , one can conclude that three replicates per individual, as used in the present study, may be sufficient. In comparison with other validation studies, the present study also has the advantage of having sufficient statistical power, given its large sample size (Cade et al. 2002).

Although we were not able to control for seasonal variation in dietary intakes as the fieldwork was only carried out in wintertime, we prevented differences between the different days

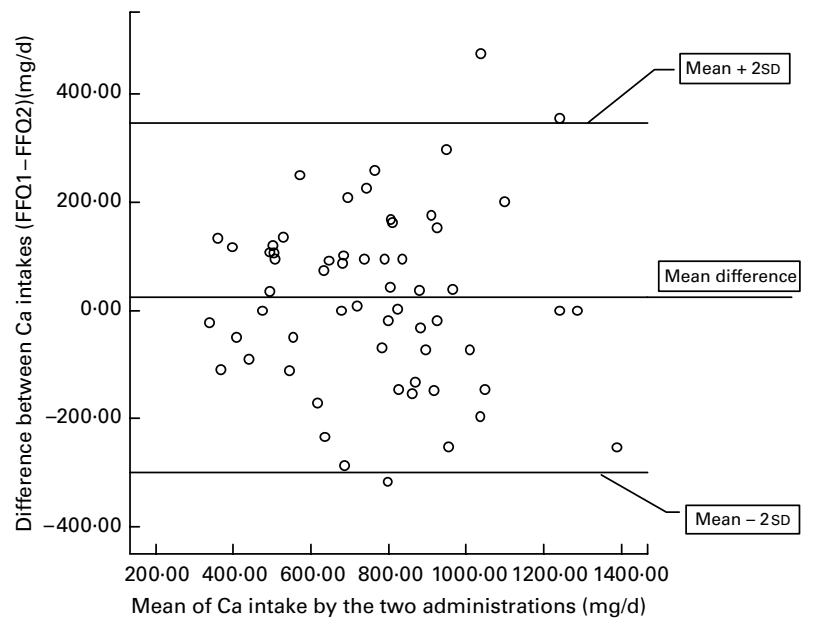

Fig. 3. Differences between the mean $\mathrm{Ca}$ intake for the first and second foodfrequency questionnaire (FFQ) administration in the reproducibility analyses. For details of subjects and procedures, see p. 803. of the week, by determining beforehand the days of the week each parent had to register in the EDR.

In the present study, $75 \%$ of the subjects returned the FFQ, while only $50 \%$ registered an EDR in addition. Besides a greater boredom and lower motivation of the respondents, the higher respondent burden of the EDR may be responsible for the reduced response rate of the EDR. Although, no doubt, willingness to participate leads to some selection bias, these data represent a more general population of preschool children in Flanders, in comparison with other food consumption surveys in children, which are mostly restricted to local areas.

The total number of children included in the validity analysis was further reduced, since several children did not reach the stringent inclusion criteria specified for the validity analysis: a 'good-quality' EDR and no missing values in the frequency and/or portion size questions of the FFQ.

Although we have our suspicions that some parents skipped questions in the FFQ, when their child never consumed the particular product, instead of indicating 'never or less than once per month', the authors preferred not to make any assumptions and did not replace these missing values. Since the questionnaires were anonymous (in order to prevent social desirable behaviour of the parents), it was thus impossible to solve any missing values by contacting the parents. Consequently, for these subjects no daily $\mathrm{Ca}$ intake ( = sum of $\mathrm{Ca}$ content of all the different products, multiplied by the frequency and portion size) could be calculated from their FFQ. However, no significant differences in mean daily $\mathrm{Ca}$ and energy intakes (calculated from their EDR) or in socio-demographic characteristics were found between children excluded and those included in the analysis.

No significant confounding factors were determined in the covariance analysis. Particularly, our finding that the validity of the FFQ, using parental reports, does not appear to be compromised when children took their lunch at school is in correspondence with findings from another validation study in young children, conducted by Parrish et al. (2003).

Reproducibility study. The response rates for the first administration were much higher than those for the second administration. In the present study, 69\% returned the first FFQ, whereas only $51 \%$ returned the second FFQ. At the second administration of the FFQ a lower mean $\mathrm{Ca}$ intake was found in comparison with the first ( $3 \%$ lower), which was analogous to other studies (Goulet et al. 2004). Seasonal variation cannot explain this difference because both FFQ were administered during the same season. A possible explanation could be that boredom was higher, while the motivation of the participants was lower during the second administration.

\section{Conclusion}

When registered by parents, our semi-quantitative FFQ tended to underestimate actual daily $\mathrm{Ca}$ intakes in preschool children, and would not be appropriate for determining absolute $\mathrm{Ca}$ intakes of individuals. Other methods, such as multiple replicates of food records, may be better in estimating $\mathrm{Ca}$ intakes for individual children. However, for use in large-scale epidemiological studies, food records also have their own limitations and FFQ are more appropriate because of their 
lower respondent burden and lower workload for computing dietary information, in comparison with dietary records. Given its fairly good ability to classify subjects into extremes of $\mathrm{Ca}$ intake and to indicate children having $\mathrm{Ca}$ intakes lower than the RDA, the FFQ presented in this study is a valid tool for $\mathrm{Ca}$ intake assessments in large epidemiological studies of preschool children, using parents as a proxy.

\section{Acknowledgements}

We thank Mia Bellemans and Mieke De Maeyer, the dietitians of our team, for the data input, their important contribution to the conceptualisation of the FFQ and their helpful advice during the analysis. We also acknowledge the schools and parents who participated in this project and generously volunteered their time and knowledge. We are also grateful to Professor Van Oyen for the critical revision. Funding for this project was provided by the Belgian Nutrition Information Center.

\section{References}

Altman DG (1991) Practical Statistics for Medical Research. London: Chapman \& Hall.

Anonymous (1985) Energy and protein requirements. Report of a joint FAO/WHO/UNU Expert Consultation. World Health Organ Tech Rep Ser 724, 1-206.

Bland JM \& Altman DG (1986) Statistical methods for assessing agreement between two methods of clinical measurement. Lancet i, 307-310.

Brunner E, Stallone D, Juneja M, Bingham S \& Marmot M (2001) Dietary assessment in Whitehall II: comparison of $7 \mathrm{~d}$ diet diary and food-frequency questionnaire and validity against biomarkers. Br J Nutr 86, 405-414.

Cade J, Thompson R, Burley V \& Warm D (2002) Development, validation and utilisation of food-frequency questionnaires - a review. Public Health Nutr 5, 567-587.

Cole TJ, Bellizzi MC, Flegal KM \& Dietz WH (2000) Establishing a standard definition for child overweight and obesity worldwide: international survey. BMJ 320, 1240-1243.

Commission of the European Communities (1993) Report of the Scientific Committee for Food: Nutrient and Energy Intakes for the European Community (Thirty-first series of Food - Science and Techniques). Luxembourg: Office for Official Publications of the European Community.

Davies JH, Evans BA \& Gregory JW (2005) Bone mass acquisition in healthy children. Arch Dis Child 90, 373-378.

Davies PS, Coward WA, Gregory J, White A \& Mills A (1994) Total energy expenditure and energy intake in the pre-school child: a comparison. Br J Nutr 72, 13-20.

Flemish Institute for Health Promotion (2004) De Voedingsdriehoek: een Praktische Voedingsgids. Brussels: Vlaams Instituut voor Gezondheidspromotie.

Food Standards Agency (2002) McCance and Widdowson's The Composition of Foods, 6th summary ed. Cambridge, UK: Royal Society of Chemistry.

Gibson RS (1987) Sources of error and variability in dietary assessment methods: a review. J Can Diet Assoc 48, 150-155.

Goulet J, Nadeau G, Lapointe A, Lamarche B \& Lemieux S (2004) Validity and reproducibility of an interviewer-administered food frequency questionnaire for healthy French-Canadian men and women. Nutr J 3, 13.

Institut Paul Lambin (2004) Table de Composition des Aliments 2004. Bruxelles: Institut Paul Lambin.
Johnston CC, Miller JZ, Slemenda CW, Reister TK, Hui S, Christian JC \& Peacock M (1992) Calcium supplementation and increases in bone mineral density in children. N Engl J Med 327, $82-87$.

Kalkwarf HJ, Khoury JC \& Lanphear BP (2003) Milk intake during childhood and adolescence, adult bone density, and osteoporotic fractures in US women. Am J Clin Nutr 77, 257-265.

Lanigan JA, Wells JC, Lawson MS \& Lucas A (2001) Validation of food diary method for assessment of dietary energy and macronutrient intake in infants and children aged 6-24 months. Eur J Clin Nutr 55, 124-129.

Matkovic V (1992) Osteoporosis as a pediatric disease: role of calcium and heredity. J Rheumatol 33, Suppl., 54-59.

Matthys C, de Henauw S, Devos C \& De Backer G (2003) Estimated energy intake, macronutrient intake and meal pattern of Flemish adolescents. Eur J Clin Nutr 57, 366-375.

Montomoli M, Gonnelli S, Giacchi M, Mattei R, Cuda C, Rossi S \& Gennari C (2002) Validation of a food frequency questionnaire for nutritional calcium intake assessment in Italian women. Eur J Clin Nutr 56, 21-30.

Nationale Raad voor de Voeding (2005) Voedingsaanbevelingen voor België 2005. Brussels: Hoge Gezondheidsraad, Ministerie van Sociale Zaken, Volksgezondheid en Leefmilieu.

Nelson M, Black AE, Morris JA \& Cole TJ (1989) Between- and within-subject variation in nutrient intake from infancy to old age: estimating the number of days required to rank dietary intakes with desired precision. Am J Clin Nutr 50, 155-167.

NEVO Foundation (2001) NEVO Tabel, Nederlands Voedingsstoffenbestand (Dutch Food Composition Table). Zeist, The Netherlands: NEVO Foundation.

NUBEL (2004) Belgische Voedinsmiddelentabel (Belgian Food Composition Table), 4th ed. Brussels: Ministerie van Volksgezondheid.

Palaniappan U, Cue RI, Payette H \& Gray-Donald K (2003) Implications of day-to-day variability on measurements of usual food and nutrient intakes. J Nutr 133, 232-235.

Parrish LA, Marshall JA, Krebs NF, Rewers M \& Norris JM (2003) Validation of a food frequency questionnaire in preschool children. Epidemiology 14, 213-217.

Rosner B \& Willett WC (1988) Interval estimates for correlation coefficients corrected for within-person variation: implications for study design and hypothesis testing. Am J Epidemiol 127, $377-386$.

Schofield WN (1985) Predicting basal metabolic rate, new standards and review of previous work. Hum Nutr Clin Nutr 39, Suppl. 1, $5-41$.

Taylor RW \& Goulding A (1998) Validation of a short food frequency questionnaire to assess calcium intake in children aged 3 to 6 years. Eur J Clin Nutr 52, 464-465.

Torun B, Davies PS, Livingstone MB, Paolisso M, Sackett R \& Spurr GB (1996) Energy requirements and dietary energy recommendations for children and adolescents 1 to 18 years old. Eur J Clin Nutr 50, Suppl. 1, S37-S80.

Treiber FA, Leonard SB, Frank G, Musante L, Davis H, Strong WB \& Levy M (1990) Dietary assessment instruments for preschool children: reliability of parental responses to the 24-hour recall and a food frequency questionnaire. J Am Diet Assoc 90, 814-820.

Willett WC (1998) Nutritional Epidemiology, 2nd ed, New York: Oxford University Press.

Wilson AM \& Lewis RD (2004) Disagreement of energy and macronutrient intakes estimated from a food frequency questionnaire and 3-day diet record in girls 4 to 9 years of age. J Am Diet Assoc 104, 373-378.

Wilson P \& Horwath C (1996) Validation of a short food frequency questionnaire for assessment of dietary calcium intake in women. Eur J Clin Nutr 50, 220-228. 


\section{Appendix \\ Food-frequency questionnaire}

\section{General remark}

In this food-frequency questionnaire we inquire into the food habits of your child. Therefore it is important that this questionnaire is completed by the person who spends most time with the child (school time excepted).

In the following table a variety of food products (food groups) is listed. Please describe (as exact as possible) how often your child eats or drinks the listed products and indicate the average portion your child consumes on that day. Consider also the meals taken at school and/or other products consumed at school.

\section{How often (frequency)?}

In the column with the heading 'How often does your child consume the following products?', there are 6 possible answers:

never or less than once per month

$1-3$ days per month

1 day per week

2-4 days per week

5-6 days per week

every day
How much?

In the column with the heading 'and what is the average portion per day?', 3 or 4 portion size options are given.

In the column with the heading 'Example portion sizes', a number of directive weights and measures are given. These can help you to quantify the average portion sizes consumed by your child on the day of consumption.

Indicate your choice by filling in the circle near the answer that is most suitable for your child.

\section{Example}

A child eats 2 big slices of bread every morning and 3 big slices of bread in the evening.

On Sunday morning, he/she eats 2 small slices of sugarbread instead of normal bread.

Every morning he/she drinks a cup of milk at home and a carton of chocolate milk at school (5 days per week).

During the weekend he/she takes a beaker of whole milk instead of a carton of chocolate milk.

Example Food-frequency questionnaire

\begin{tabular}{|c|c|c|c|}
\hline Food groups & $\begin{array}{l}\text { How often does your child } \\
\text { consume the following products? }\end{array}$ & $\begin{array}{c}\text { and what is the average } \\
\text { portion per day? }\end{array}$ & Example portion sizes \\
\hline Sweet bread (sugarbread, raisinbread...) & $\begin{array}{l}\text { never or less than once } \\
\text { per month } \\
\text { 1-3 days per month } \\
\text { 1 day per week } \\
2-4 \text { days per week } \\
2-4 \text { days per week } \\
5-6 \text { days per week } \\
\text { every day }\end{array}$ & $\begin{array}{l}\text { - } 40 \mathrm{~g} \text { or less } \\
\text { between } 40 \text { and } 120 \mathrm{~g} \\
\text { 120 g or more }\end{array}$ & $\begin{array}{l}1 \text { slice of a big } \\
\text { bread }=30 \mathrm{~g} \\
1 \text { slice of a small } \\
\text { bread }=20 \mathrm{~g}\end{array}$ \\
\hline Bread/rusk/crusted roll/French bread/rice wafer & $\begin{array}{l}\text { never or less than once per month } \\
1-3 \text { days per month } \\
1 \text { day per week } \\
2-4 \text { days per week } \\
5-6 \text { days per week } \\
\text { every day }\end{array}$ & $\begin{array}{l}\bigcirc 40 \mathrm{~g} \text { or less } \\
\text { between } 40 \text { and } 120 \mathrm{~g} \\
\text { - } 120 \mathrm{~g} \text { or less }\end{array}$ & $\begin{array}{l}1 \text { slice of a big bread }=30 \mathrm{~g} \\
1 \text { slice of a small bread }=20 \mathrm{~g} \\
1 \text { rusk }=10 \mathrm{~g} \\
1 \text { crusted roll }=40 \mathrm{~g}\end{array}$ \\
\hline $\begin{array}{l}\text { Milk (not aromatised and without } \\
\text { additional sugars) }\end{array}$ & $\begin{array}{l}\text { never or less than once per month } \\
1-3 \text { days per month } \\
1 \text { day per week } \\
\text { 2-4 days per week } \\
5-6 \text { days per week } \\
\text { - every day }\end{array}$ & $\begin{array}{l}\text { - between } 200 \text { and } 400 \mathrm{ml} \\
\text { o between } 400 \text { and } 600 \mathrm{ml} \\
600 \mathrm{ml} \text { or more }\end{array}$ & $\begin{array}{l}1 \text { beaker }=225 \mathrm{ml} \\
1 \text { glass }=150 \mathrm{ml} \\
1 \text { carton }=200 \mathrm{ml} \\
1 \text { cup }=125 \mathrm{ml} \\
1 \text { breakfast bowl }=125 \mathrm{ml}\end{array}$ \\
\hline
\end{tabular}

Food-frequency questionnaire

\begin{tabular}{|c|c|c|c|}
\hline Food groups & $\begin{array}{l}\text { How often does your child } \\
\text { consume the following products? }\end{array}$ & $\begin{array}{l}\text { and what is the average } \\
\text { portion per day? }\end{array}$ & Example portion sizes \\
\hline Water (tap water, bottled water...) & $\begin{array}{l}\text { never or less than once per month } \\
1-3 \text { days per month } \\
1 \text { day per week } \\
2-4 \text { days per week } \\
5-6 \text { days per week } \\
\text { every day }\end{array}$ & $\begin{array}{l}O 200 \mathrm{ml} \text { or less } \\
\text { between } 200 \text { and } 400 \mathrm{ml} \\
\text { between } 400 \text { and } 600 \mathrm{ml} \\
600 \mathrm{ml} \text { or more }\end{array}$ & $\begin{array}{l}1 \text { glass }=150 \mathrm{ml} \\
1 \text { beaker }=225 \mathrm{ml}\end{array}$ \\
\hline
\end{tabular}




\begin{tabular}{|c|c|c|c|}
\hline Food groups & $\begin{array}{l}\text { How often does your child } \\
\text { consume the following products? }\end{array}$ & $\begin{array}{l}\text { and what is the average } \\
\text { portion per day? }\end{array}$ & Example portion sizes \\
\hline Coffee and tea without sugar & $\begin{array}{l}\text { never or less than once per month } \\
1-3 \text { days per month } \\
1 \text { day per week } \\
2-4 \text { days per week } \\
5-6 \text { days per week } \\
\text { every day }\end{array}$ & $\begin{array}{l}\circ 200 \mathrm{ml} \text { or less } \\
\text { O between } 200 \text { and } 400 \mathrm{ml} \\
\text { b between } 400 \text { and } 600 \mathrm{ml} \\
600 \mathrm{ml} \text { or more }\end{array}$ & $\begin{array}{l}1 \text { cup }=125 \mathrm{ml} \\
1 \text { beaker }=225 \mathrm{ml}\end{array}$ \\
\hline Coffee and tea with sugar & $\begin{array}{l}\text { never or less than once per month } \\
\text { 1-3 days per month } \\
1 \text { day per week } \\
\text { 2-4 days per week } \\
5-6 \text { days per week } \\
\text { every day }\end{array}$ & $\begin{array}{l}\circ 200 \mathrm{ml} \text { or less } \\
\text { O between } 200 \text { and } 400 \mathrm{ml} \\
O \text { between } 400 \text { and } 600 \mathrm{ml} \\
600 \mathrm{ml} \text { or more }\end{array}$ & $\begin{array}{l}1 \text { cup }=125 \mathrm{ml} \\
1 \text { beaker }=225 \mathrm{ml}\end{array}$ \\
\hline Fruit juice & $\begin{array}{l}\text { never or less than once per month } \\
1-3 \text { days per month } \\
1 \text { day per week } \\
2-4 \text { days per week } \\
5-6 \text { days per week } \\
\text { every day }\end{array}$ & $\begin{array}{l}\text { 200 } \mathrm{ml} \text { or less } \\
\text { between } 200 \text { and } 400 \mathrm{ml} \\
\text { between } 400 \text { and } 600 \mathrm{ml} \\
600 \mathrm{ml} \text { or more }\end{array}$ & $\begin{array}{l}1 \text { carton }=200 \mathrm{ml} \\
1 \text { beaker }=225 \mathrm{ml} \\
1 \text { glass }=150 \mathrm{ml}\end{array}$ \\
\hline $\begin{array}{l}\text { Diet beverages (diet soda drinks, e.g. } \\
\text { diet cola...) }\end{array}$ & $\begin{array}{l}\text { never or less than once per month } \\
1-3 \text { days per month } \\
1 \text { day per week } \\
\text { 2-4 days per week } \\
5-6 \text { days per week } \\
\text { every day }\end{array}$ & $\begin{array}{l}\circ 200 \mathrm{ml} \text { or less } \\
\text { o between } 200 \text { and } 400 \mathrm{ml} \\
\text { between } 400 \text { and } 600 \mathrm{ml} \\
600 \mathrm{ml} \text { or more }\end{array}$ & $\begin{array}{l}1 \text { glass }=150 \mathrm{ml} \\
1 \mathrm{can}=330 \mathrm{ml} \\
1 \text { beaker }=225 \mathrm{ml}\end{array}$ \\
\hline $\begin{array}{l}\text { Sugared beverages (soda drinks such as } \\
\text { cola, lemonade, iced tea...) }\end{array}$ & $\begin{array}{l}\text { never or less than once per month } \\
1-3 \text { days per month } \\
1 \text { day per week } \\
\text { 2-4 days per week } \\
5-6 \text { days per week } \\
\text { every day }\end{array}$ & $\begin{array}{l}200 \mathrm{ml} \text { or less } \\
0 \text { between } 200 \text { and } 400 \mathrm{ml} \\
0 \text { between } 400 \text { and } 600 \mathrm{ml} \\
600 \mathrm{ml} \text { or more }\end{array}$ & $\begin{array}{l}1 \text { glass }=150 \mathrm{ml} \\
1 \text { can }=330 \mathrm{ml} \\
1 \text { carton }=200 \mathrm{ml} \\
1 \text { beaker }=225 \mathrm{ml}\end{array}$ \\
\hline Soup & $\begin{array}{l}\text { never or less than once per month } \\
1-3 \text { days per month } \\
1 \text { day per week } \\
\text { 2-4 days per week } \\
5-6 \text { days per week } \\
\text { every day }\end{array}$ & $\begin{array}{l}\circ 200 \mathrm{ml} \text { or less } \\
\text { O between } 200 \text { and } 400 \mathrm{ml} \\
\text { o between } 400 \text { and } 600 \mathrm{ml} \\
600 \mathrm{ml} \text { or more }\end{array}$ & $\begin{array}{l}1 \text { soup bowl }=250 \mathrm{ml} \\
1 \text { bowl }=250 \mathrm{ml} \\
1 \text { beaker }=225 \mathrm{ml}\end{array}$ \\
\hline Vegetable beverages & $\begin{array}{l}\text { never or less than once per month } \\
1-3 \text { days per month } \\
1 \text { day per week } \\
\text { 2-4 days per week } \\
5-6 \text { days per week } \\
\text { every day }\end{array}$ & $\begin{array}{l}\circ 200 \mathrm{ml} \text { or less } \\
\text { o between } 200 \text { and } 400 \mathrm{ml} \\
\text { between } 400 \text { and } 600 \mathrm{ml} \\
600 \mathrm{ml} \text { or more }\end{array}$ & $\begin{array}{l}1 \text { glass }=150 \mathrm{ml} \\
1 \text { cup }=125 \mathrm{ml} \\
1 \text { beaker }=225 \mathrm{ml} \\
1 \mathrm{~V} 8 \text { can }=330 \mathrm{ml} \\
1 \text { Looza or Trudo bottle }=200 \mathrm{ml}\end{array}$ \\
\hline Yakult, Actimel and the like & $\begin{array}{l}\text { never or less than once per month } \\
1-3 \text { days per month } \\
1 \text { day per week } \\
\text { 2-4 days per week } \\
5-6 \text { days per week } \\
\text { every day }\end{array}$ & $\begin{array}{l}\text { 40 ml or less } \\
\text { between } 40 \text { and } 120 \mathrm{ml} \\
120 \mathrm{ml} \text { or more }\end{array}$ & $\begin{array}{l}1 \text { Yakult }=65 \mathrm{ml} \\
1 \text { Actimel }=100 \mathrm{ml}\end{array}$ \\
\hline Soya beverages & $\begin{array}{l}\text { never or less than once per month } \\
1-3 \text { days per month } \\
1 \text { day per week } \\
\text { 2-4 days per week } \\
5-6 \text { days per week } \\
\text { every day }\end{array}$ & $\begin{array}{l}\text { 200 } \mathrm{ml} \text { or less } \\
\text { between } 200 \text { and } 400 \mathrm{ml} \\
\text { between } 400 \text { and } 600 \mathrm{ml} \\
600 \mathrm{ml} \text { or more }\end{array}$ & $\begin{array}{l}1 \text { soya drink }=250 \mathrm{ml} \\
1 \text { beaker }=225 \mathrm{ml} \\
1 \text { glass }=150 \mathrm{ml} \\
1 \text { breakfast bowl } \\
\text { (with cereals) }=125 \mathrm{ml}\end{array}$ \\
\hline $\begin{array}{l}\text { Sugared milk (e.g. flavoured milk, chocolate } \\
\text { milk, porridge, buttermilk with sugar...) }\end{array}$ & $\begin{array}{l}\text { never or less than once per month } \\
1-3 \text { days per month } \\
1 \text { day per week } \\
\text { 2-4 days per week } \\
5-6 \text { days per week } \\
\text { every day }\end{array}$ & $\begin{array}{l}\text { 200 ml or less } \\
\text { between } 200 \text { and } 400 \mathrm{ml} \\
\text { between } 400 \text { and } 600 \mathrm{ml} \\
600 \mathrm{ml} \text { or more }\end{array}$ & $\begin{array}{l}1 \text { beaker }=225 \mathrm{ml} \\
1 \text { glass }=150 \mathrm{ml} \\
1 \text { carton }=200 \mathrm{ml} \\
1 \text { cup }=125 \mathrm{ml} \\
1 \text { bowl }=250 \mathrm{ml}\end{array}$ \\
\hline $\begin{array}{l}\text { Milk (not aromatised and without additional } \\
\text { sugars) }\end{array}$ & $\begin{array}{l}\text { never or less than once per month } \\
\text { 1-3 days per month } \\
1 \text { day per week } \\
\text { 2-4 days per week } \\
5-6 \text { days per week } \\
\text { every day }\end{array}$ & $\begin{array}{l}\text { 200 } \mathrm{ml} \text { or less } \\
\text { between } 200 \text { and } 400 \mathrm{ml} \\
\text { between } 400 \text { and } 600 \mathrm{ml} \\
600 \mathrm{ml} \text { or more }\end{array}$ & $\begin{array}{l}1 \text { beaker }=225 \mathrm{ml} \\
1 \text { glass }=150 \mathrm{ml} \\
1 \text { carton }=200 \mathrm{ml} \\
1 \text { cup }=125 \mathrm{ml} \\
1 \text { breakfast bowl } \\
\text { (with cereals) }=125 \mathrm{ml}\end{array}$ \\
\hline
\end{tabular}




\begin{tabular}{|c|c|c|c|}
\hline Food groups & $\begin{array}{l}\text { How often does your child } \\
\text { consume the following products? }\end{array}$ & $\begin{array}{l}\text { and what is the average } \\
\text { portion per day? }\end{array}$ & Example portion sizes \\
\hline Fresh cheese (e.g. Petit Gervais, Jogging...) & $\begin{array}{l}\text { never or less than once per month } \\
1-3 \text { days per month } \\
1 \text { day per week } \\
\text { 2-4 days per week } \\
5-6 \text { days per week } \\
\text { every day }\end{array}$ & $\begin{array}{l}O 65 \mathrm{~g} \text { or less } \\
\text { between } 65 \text { and } 195 \mathrm{~g} \\
0195 \mathrm{~g} \text { or more }\end{array}$ & $\begin{array}{l}1 \text { small pot of Petit Gervais }=55 \mathrm{~g} \\
1 \text { large pot of Petit Gervais } \\
\text { (maxi) }=100 \mathrm{~g} \\
1 \text { pot of Jogging } \\
(\text { Aldi })=150 \mathrm{~g}\end{array}$ \\
\hline $\begin{array}{l}\text { Sugared or aromatised yoghurt (fruit yoghurt, } \\
\text { yoghurt in which you add sugar...) }\end{array}$ & $\begin{array}{l}\text { never or less than once per month } \\
1-3 \text { days per month } \\
1 \text { day per week } \\
\text { 2-4 days per week } \\
5-6 \text { days per week } \\
\text { every day }\end{array}$ & $\begin{array}{l}O 65 \mathrm{~g} \text { or less } \\
\text { between } 65 \text { and } 195 \mathrm{~g} \\
195 \mathrm{~g} \text { or more }\end{array}$ & $\begin{array}{l}1 \text { pot of yoghurt }=125 \mathrm{~g} \\
1 \text { small pot of yoghurt (type } \\
\text { Teletubbies Stassano) }=100 \mathrm{~g}\end{array}$ \\
\hline Yoghurt (without additional sugars) & $\begin{array}{l}\text { never or less than once per month } \\
1-3 \text { days per month } \\
1 \text { day per week } \\
\text { 2-4 days per week } \\
5-6 \text { days per week } \\
\text { every day }\end{array}$ & $\begin{array}{l}O 65 \mathrm{~g} \text { or less } \\
\text { between } 65 \text { and } 195 \mathrm{~g} \\
195 \mathrm{~g} \text { or more }\end{array}$ & $\begin{array}{l}1 \text { pot of yoghurt }=125 \mathrm{~g} \\
1 \text { dish }=150 \mathrm{~g} \\
1 \text { bowl }=250 \mathrm{ml} \\
1 \text { cup }=125 \mathrm{ml}\end{array}$ \\
\hline Soya-based desserts & $\begin{array}{l}\text { never or less than once per month } \\
1-3 \text { days per month } \\
1 \text { day per week } \\
2-4 \text { days per week } \\
5-6 \text { days per week } \\
\text { every day }\end{array}$ & $\begin{array}{l}065 \mathrm{~g} \text { or less } \\
\text { between } 65 \text { and } 195 \mathrm{~g} \\
195 \mathrm{~g} \text { or more }\end{array}$ & 1 pot of Alpro soya dessert $=125 \mathrm{~g}$ \\
\hline $\begin{array}{l}\text { Milk-based desserts (pudding, rice pudding, } \\
\text { milkshake, jelly...) }\end{array}$ & $\begin{array}{l}\text { never or less than once per month } \\
1-3 \text { days per month } \\
1 \text { day per week } \\
2-4 \text { days per week } \\
5-6 \text { days per week } \\
\text { every day }\end{array}$ & $\begin{array}{l}\circ 65 \mathrm{~g} \text { or less } \\
\text { between } 65 \text { and } 195 \mathrm{~g} \\
195 \mathrm{~g} \text { or more }\end{array}$ & $\begin{array}{l}1 \text { pot of pudding }=125 \mathrm{~g} \\
1 \text { pot of rice pudding }=100 \mathrm{~g}\end{array}$ \\
\hline Chocolate mousse, ice cream, tiramisu... & $\begin{array}{l}\text { never or less than once per month } \\
\text { 1-3 days per month } \\
1 \text { day per week } \\
\text { 2-4 days per week } \\
5-6 \text { days per week } \\
\text { every day }\end{array}$ & $\begin{array}{l}\circ 65 \mathrm{~g} \text { or less } \\
\text { between } 65 \text { and } 195 \mathrm{~g} \\
195 \mathrm{~g} \text { or more }\end{array}$ & $\begin{array}{l}1 \text { pot of chocolate mousse }=100 \mathrm{~g} \\
1 \text { scoop of ice cream }=50 \mathrm{~g}\end{array}$ \\
\hline Nuts and seeds & $\begin{array}{l}\text { never or less than once per month } \\
1-3 \text { days per month } \\
1 \text { day per week } \\
2-4 \text { days per week } \\
5-6 \text { days per week } \\
\text { every day }\end{array}$ & $\begin{array}{l}25 \mathrm{~g} \text { or less } \\
\text { between } 25 \text { and } 75 \mathrm{~g} \\
75 \mathrm{~g} \text { or more }\end{array}$ & $\begin{array}{l}10 \text { peanuts without shells }=20 \mathrm{~g} \\
1 \text { tablespoon of nuts }=25 \mathrm{~g}\end{array}$ \\
\hline Olives & $\begin{array}{l}\text { never or less than once per month } \\
\text { 1-3 days per month } \\
1 \text { day per week } \\
\text { 2-4 days per week } \\
5-6 \text { days per week } \\
\text { every day }\end{array}$ & $\begin{array}{l}20 \mathrm{~g} \text { or less } \\
\text { between } 20 \text { and } 60 \mathrm{~g} \\
60 \mathrm{~g} \text { or more }\end{array}$ & $\begin{array}{l}5 \text { olives }=20 \mathrm{~g} \\
15 \text { olives }=60 \mathrm{~g}\end{array}$ \\
\hline Dried fruit & $\begin{array}{l}\text { never or less than once per month } \\
1-3 \text { days per month } \\
1 \text { day per week } \\
\text { 2-4 days per week } \\
5-6 \text { days per week } \\
\text { every day }\end{array}$ & $\begin{array}{l}\text { } 1 \text { tablespoon } \\
\text { 1-3 tablespoons } \\
3 \text { tablespoons }\end{array}$ & $\begin{array}{l}1 \text { tablespoon of dried fruit }=1 \\
\text { dried fig }=20 \mathrm{~g}\end{array}$ \\
\hline Canned fruit & $\begin{array}{l}\text { never or less than once per month } \\
1-3 \text { days per month } \\
1 \text { day per week } \\
\text { 2-4 days per week } \\
5-6 \text { days per week } \\
\text { every day }\end{array}$ & $\begin{array}{l}75 \mathrm{~g} \text { or less } \\
\text { between } 75 \text { and } 225 \mathrm{~g} \\
225 \mathrm{~g} \text { or more }\end{array}$ & $\begin{array}{l}1 \text { slice of canned pineapple }=35 \mathrm{~g} \\
1 \text { dish of black cherries }=100 \mathrm{~g} \\
1 \text { half apricot canned with } \\
\text { syrup }=17 \mathrm{~g}\end{array}$ \\
\hline Fresh fruit & $\begin{array}{l}\text { never or less than once per month } \\
1-3 \text { days per month } \\
1 \text { day per week } \\
2-4 \text { days per week } \\
5-6 \text { days per week } \\
\text { every day }\end{array}$ & $\begin{array}{l}075 \mathrm{~g} \text { or less } \\
\text { between } 75 \text { and } 225 \mathrm{~g} \\
225 \mathrm{~g} \text { or more }\end{array}$ & $\begin{array}{l}1 \mathrm{kiwi}=75 \mathrm{~g} \\
1 \text { orange }=140 \mathrm{~g} \\
1 \text { tangerine }=60 \mathrm{~g} \\
1 \text { small apple }=125 \mathrm{~g} \\
\text { other fruit }=130 \mathrm{~g}\end{array}$ \\
\hline
\end{tabular}




\begin{tabular}{|c|c|c|c|}
\hline Food groups & $\begin{array}{l}\text { How often does your child } \\
\text { consume the following products? }\end{array}$ & $\begin{array}{l}\text { and what is the average } \\
\text { portion per day? }\end{array}$ & Example portion sizes \\
\hline Chocolate & $\begin{array}{l}\text { never or less than once per month } \\
\text { 1-3 days per month } \\
1 \text { day per week } \\
2-4 \text { days per week } \\
5-6 \text { days per week } \\
\text { every day }\end{array}$ & $\begin{array}{l}25 \mathrm{~g} \text { or less } \\
0 \text { between } 25 \text { and } 75 \mathrm{~g} \\
75 \mathrm{~g} \text { or more }\end{array}$ & $\begin{array}{l}1 \text { individual bar of chocolate }=50 \mathrm{~g} \\
1 \text { bar of a big package of } 200 \mathrm{~g}=25 \mathrm{~g} \\
1 \text { slice (type Mignonnette) }=10 \mathrm{~g}\end{array}$ \\
\hline $\begin{array}{l}\text { Sweet snacks (pastry, biscuits ... no-milk } \\
\text { desserts or soya desserts) }\end{array}$ & $\begin{array}{l}\text { never or less than once per month } \\
1-3 \text { days per month } \\
1 \text { day per week } \\
\text { 2-4 days per week } \\
5-6 \text { days per week } \\
\text { every day }\end{array}$ & $\begin{array}{l}25 \mathrm{~g} \text { or less } \\
\text { between } 25 \text { and } 75 \mathrm{~g} \\
75 \mathrm{~g} \text { or more }\end{array}$ & $\begin{array}{l}1 \text { Belgian waffle }=50 \mathrm{~g} \\
1 \text { package Vitabis }=25 \mathrm{~g} \\
1 \text { filled biscuit (type chocoprince) } \\
\quad=25 \mathrm{~g}\end{array}$ \\
\hline Salty snacks (crisps, salted biscuits...) & $\begin{array}{l}\text { never or less than once per month } \\
\text { 1-3 days per month } \\
1 \text { day per week } \\
2-4 \text { days per week } \\
\text { 5-6 days per week } \\
\text { every day }\end{array}$ & $\begin{array}{l}025 \mathrm{~g} \text { or less } \\
\text { between } 25 \text { and } 75 \mathrm{~g} \\
75 \mathrm{~g} \text { or more }\end{array}$ & $\begin{array}{l}1 \text { small bag of crisps }=30 \mathrm{~g} \\
1 \text { Tuc biscuit }=3 \mathrm{~g} \\
(1 \text { package of Tuc biscuits }=100 \mathrm{~g} \text { ) }\end{array}$ \\
\hline $\begin{array}{l}\text { Coffee cake (chocolate roll, croissant, } \\
\text { raisin biscuit) }\end{array}$ & $\begin{array}{l}\text { never or less than once per month } \\
1-3 \text { days per month } \\
1 \text { day per week } \\
2-4 \text { days per week } \\
5-6 \text { days per week } \\
\text { every day }\end{array}$ & $\begin{array}{l}\text { half a coffee cake or less } \\
1 \text { coffee cake } \\
1.5 \text { coffee cake or more }\end{array}$ & 1 medium coffee cake $=55 \mathrm{~g}$ \\
\hline Breakfast cereals (muesli, cornflakes) & $\begin{array}{l}\text { never or less than once per month } \\
1-3 \text { days per month } \\
1 \text { day per week } \\
2-4 \text { days per week } \\
5-6 \text { days per week } \\
\text { every day }\end{array}$ & $\begin{array}{l}15 \mathrm{~g} \text { or less } \\
\text { between } 15 \text { and } 45 \mathrm{~g} \\
45 \mathrm{~g} \text { or more }\end{array}$ & $\begin{array}{l}1 \text { bowl of cereals }=30 \mathrm{~g} \\
1 \text { individual box }=30 \mathrm{~g}\end{array}$ \\
\hline Sweet bread (sugarbread, raisinbread...) & $\begin{array}{l}\text { never or less than once per month } \\
1-3 \text { days per month } \\
1 \text { day per week } \\
\text { 2-4 days per week } \\
5-6 \text { days per week } \\
\text { every day }\end{array}$ & $\begin{array}{l}\circ 40 \mathrm{~g} \text { or less } \\
0 \text { between } 40 \text { and } 120 \mathrm{~g} \\
120 \mathrm{~g} \text { or more }\end{array}$ & $\begin{array}{l}1 \text { slice of a big bread }=30 \mathrm{~g} \\
1 \text { slice of a small bread }=20 \mathrm{~g}\end{array}$ \\
\hline $\begin{array}{l}\text { Bread/rusk/crusted roll/French } \\
\text { bread/rice wafer }\end{array}$ & $\begin{array}{l}\text { never or less than once per month } \\
1-3 \text { days per month } \\
1 \text { day per week } \\
2-4 \text { days per week } \\
5-6 \text { days per week } \\
\text { every day }\end{array}$ & $\begin{array}{l}\circ 40 \mathrm{~g} \text { or less } \\
0 \text { between } 40 \text { and } 120 \mathrm{~g} \\
120 \mathrm{~g} \text { or more }\end{array}$ & $\begin{array}{l}1 \text { slice of a big bread }=30 \mathrm{~g} \\
1 \text { slice of a small bread }=20 \mathrm{~g} \\
1 \text { rusk }=10 \mathrm{~g} \\
1 \text { crusted roll }=40 \mathrm{~g}\end{array}$ \\
\hline Chocolate spread, sprinklers or flakes & $\begin{array}{l}\text { never or less than once per month } \\
\text { 1-3 days per month } \\
1 \text { day per week } \\
2-4 \text { days per week } \\
\text { 5-6 days per week } \\
\text { every day }\end{array}$ & $\begin{array}{l}15 \mathrm{~g} \text { or less } \\
\text { between } 15 \text { and } 45 \mathrm{~g} \\
45 \mathrm{~g} \text { or more }\end{array}$ & $\begin{array}{l}15 \mathrm{~g} \text { for } 1 \text { large loaf } \\
10 \mathrm{~g} \text { for } 1 \text { small loaf }\end{array}$ \\
\hline $\begin{array}{l}\text { Other sweet spread (honey, jam or } \\
\text { marmalade...) }\end{array}$ & $\begin{array}{l}\text { never or less than once per month } \\
1-3 \text { days per month } \\
1 \text { day per week } \\
2-4 \text { days per week } \\
5-6 \text { days per week } \\
\text { every day }\end{array}$ & $\begin{array}{l}15 \mathrm{~g} \text { or less } \\
0 \text { between } 15 \text { and } 45 \mathrm{~g} \\
45 \mathrm{~g} \text { or more }\end{array}$ & $\begin{array}{l}15 \mathrm{~g} \text { for } 1 \text { large loaf } \\
10 \mathrm{~g} \text { for } 1 \text { small loaf }\end{array}$ \\
\hline $\begin{array}{l}\text { Cheese spread/melted cheese (fondue, } \\
\text { slice of cheese) }\end{array}$ & $\begin{array}{l}\text { never or less than once per month } \\
1-3 \text { days per month } \\
1 \text { day per week } \\
2-4 \text { days per week } \\
5-6 \text { days per week } \\
\text { every day }\end{array}$ & $\begin{array}{l}10 \mathrm{~g} \text { or less } \\
\text { between } 10 \text { and } 30 \mathrm{~g} \\
30 \mathrm{~g} \text { or more }\end{array}$ & $\begin{array}{l}1 \text { triangle }=20 \mathrm{~g} \\
1 \text { slice }=25 \mathrm{~g}\end{array}$ \\
\hline $\begin{array}{l}\text { Hard cheese (e.g. Gouda, } \\
\text { Gruyère, Emmental...) }\end{array}$ & $\begin{array}{l}\text { never or less than once per month } \\
\text { 1-3 days per month } \\
1 \text { day per week } \\
\text { 2-4 days per week } \\
5-6 \text { days per week } \\
\text { every day }\end{array}$ & $\begin{array}{l}10 \mathrm{~g} \text { or less } \\
\text { between } 10 \text { and } 30 \mathrm{~g} \\
30 \mathrm{~g} \text { or more }\end{array}$ & $\begin{array}{l}1 \text { slice of cheese }(10 \times 10 \mathrm{~cm}) \\
\quad=25 \mathrm{~g}\end{array}$ \\
\hline
\end{tabular}




\begin{tabular}{|c|c|c|c|}
\hline Food groups & $\begin{array}{l}\text { How often does your child } \\
\text { consume the following products? }\end{array}$ & $\begin{array}{l}\text { and what is the average } \\
\text { portion per day? }\end{array}$ & Example portion sizes \\
\hline $\begin{array}{l}\text { Fish products (smoked salmon/halibut, } \\
\text { tuna salad, crab salad...) } \\
\text { (only with cold meals and with bread) }\end{array}$ & $\begin{array}{l}\text { never or less than once per month } \\
1-3 \text { days per month } \\
1 \text { day per week } \\
\text { 2-4 days per week } \\
5-6 \text { days per week } \\
\text { every day }\end{array}$ & $\begin{array}{l}15 \mathrm{~g} \text { or less } \\
\text { between } 15 \text { and } 45 \mathrm{~g} \\
45 \mathrm{~g} \text { or more }\end{array}$ & $15 \mathrm{~g}$ for 1 slice of bread \\
\hline $\begin{array}{l}\text { Meat products (sliced cold meat) (smoked } \\
\text { ham, chicken ham, salami, pâté ...) } \\
\text { (only with cold meals or with bread) }\end{array}$ & $\begin{array}{l}\text { never or less than once per month } \\
\text { 1-3 days per month } \\
1 \text { day per week } \\
2-4 \text { days per week } \\
5-6 \text { days per week } \\
\text { every day }\end{array}$ & $\begin{array}{l}15 \mathrm{~g} \text { or less } \\
\text { between } 15 \text { and } 45 \mathrm{~g} \\
45 \mathrm{~g} \text { or more }\end{array}$ & $15 \mathrm{~g}$ for 1 slice of bread \\
\hline $\begin{array}{l}\text { Eggs (not in preparations such as } \\
\text { mashed potatoes or biscuits) }\end{array}$ & $\begin{array}{l}\text { never or less than once per month } \\
1-3 \text { days per month } \\
1 \text { day per week } \\
\text { 2-4 days per week } \\
5-6 \text { days per week } \\
\text { every day }\end{array}$ & $\begin{array}{l}\bigcirc 1 \text { piece or less } \\
\circ 2 \text { pieces } \\
03 \text { pieces or more }\end{array}$ & per piece \\
\hline $\begin{array}{l}\text { Vegetarian products (e.g. Quorn, } \\
\text { tofu, pulses...) }\end{array}$ & $\begin{array}{l}\text { never or less than once per month } \\
1-3 \text { days per month } \\
1 \text { day per week } \\
\text { 2-4 days per week } \\
5-6 \text { days per week } \\
\text { every day }\end{array}$ & $\begin{array}{l}25 \mathrm{~g} \text { or less } \\
\text { between } 25 \text { and } 75 \mathrm{~g} \\
75 \mathrm{~g} \text { or more }\end{array}$ & $\begin{array}{l}1 \text { piece of tempé }=75 \mathrm{~g} \\
1 \text { small vegetarian burger }=55 \mathrm{~g} \\
1 \text { large vegetarian burger }=95 \mathrm{~g} \\
2 \text { tablespoons of cooked pulses } \\
\quad=50 \mathrm{~g}\end{array}$ \\
\hline $\begin{array}{l}\text { Fresh fish/shellfish (e.g. fresh salmon, cod, } \\
\text { shrimps, mussels...) (no smoked } \\
\text { fish products) }\end{array}$ & $\begin{array}{l}\text { never or less than once per month } \\
1-3 \text { days per month } \\
1 \text { day per week } \\
\text { 2-4 days per week } \\
5-6 \text { days per week } \\
\text { every day }\end{array}$ & $\begin{array}{l}025 \mathrm{~g} \text { or less } \\
\text { between } 25 \text { and } 75 \mathrm{~g} \\
75 \mathrm{~g} \text { or more }\end{array}$ & $\begin{array}{l}1 \text { young herring }=80 \mathrm{~g} \\
4 \text { tablespoons shrimps }=80 \mathrm{~g} \\
1 \text { fresh cod fillet }=200 \mathrm{~g} \\
1 \text { fishstick }=30 \mathrm{~g}\end{array}$ \\
\hline Poultry & $\begin{array}{l}\text { never or less than once per month } \\
1-3 \text { days per month } \\
1 \text { day per week } \\
\text { 2-4 days per week } \\
5-6 \text { days per week } \\
\text { every day }\end{array}$ & $\begin{array}{l}25 \mathrm{~g} \text { or less } \\
\text { between } 25 \text { and } 75 \mathrm{~g} \\
75 \mathrm{~g} \text { or more }\end{array}$ & $\begin{array}{l}1 \text { chicken fillet }=150 \mathrm{~g} \\
1 \text { chicken nugget }=25 \mathrm{~g}\end{array}$ \\
\hline Meat (no poultry and meat products) & $\begin{array}{l}\text { never or less than once per month } \\
1-3 \text { days per month } \\
1 \text { day per week } \\
\text { 2-4 days per week } \\
5-6 \text { days per week } \\
\text { every day }\end{array}$ & $\begin{array}{l}25 \mathrm{~g} \text { or less } \\
\text { between } 25 \text { and } 75 \mathrm{~g} \\
75 \mathrm{~g} \text { or more }\end{array}$ & $\begin{array}{l}1 \text { pork chop or } 1 \text { roast sausage } \\
(20 \mathrm{~cm}) \text { or } 1 \text { large cutlet }=130 \mathrm{~g} \\
1 \text { steak }=175 \mathrm{~g}\end{array}$ \\
\hline Pasta (spaghetti, macaroni, lasagne...) & $\begin{array}{l}\text { never or less than once per month } \\
1-3 \text { days per month } \\
1 \text { day per week } \\
\text { 2-4 days per week } \\
5-6 \text { days per week } \\
\text { every day }\end{array}$ & $\begin{array}{l}75 \mathrm{~g} \text { cooked or less } \\
\text { between } 75 \text { and } 225 \mathrm{~g} \text { cooked } \\
225 \mathrm{~g} \text { cooked or more }\end{array}$ & $\begin{array}{l}50 \mathrm{~g} \text { uncooked pasta gives } 125 \mathrm{~g} \\
\text { cooked pasta } \\
1 \text { tablespoon cooked pasta }=25 \mathrm{~g}\end{array}$ \\
\hline Rice & $\begin{array}{l}\text { never or less than once per month } \\
1-3 \text { days per month } \\
1 \text { day per week } \\
\text { 2-4 days per week } \\
5-6 \text { days per week } \\
\text { every day }\end{array}$ & $\begin{array}{l}O 75 \mathrm{~g} \text { cooked or less } \\
\text { between } 75 \text { and } 225 \mathrm{~g} \text { cooked } \\
225 \mathrm{~g} \text { cooked or more }\end{array}$ & $\begin{array}{l}40 \mathrm{~g} \text { uncooked rice or } 1 / 3 \text { of a } 2 \\
\text { persons package gives } 100 \mathrm{~g} \\
\text { boiled rice } \\
1 \text { tablespoon of cooked rice }=25 \mathrm{~g}\end{array}$ \\
\hline Fried potato products (croquettes, fries...) & $\begin{array}{l}\text { never or less than once per month } \\
\text { 1-3 days per month } \\
1 \text { day per week } \\
\text { 2-4 days per week } \\
5-6 \text { days per week } \\
\text { every day }\end{array}$ & $\begin{array}{l}O 50 \mathrm{~g} \text { or less } \\
\circ \text { between } 50 \text { and } 150 \mathrm{~g} \\
150 \mathrm{~g} \text { or more }\end{array}$ & $\begin{array}{l}2 \text { sliced potatoes or } \\
3-4 \text { croquettes or } \\
20 \text { fries }=100 \mathrm{~g}\end{array}$ \\
\hline $\begin{array}{l}\text { Potatoes (cooked, steamed, } \\
\text { baked, mashed...) }\end{array}$ & $\begin{array}{l}\text { never or less than once per month } \\
1-3 \text { days per month } \\
1 \text { day per week } \\
2-4 \text { days per week } \\
5-6 \text { days per week } \\
\text { every day }\end{array}$ & $\begin{array}{l}\text { } 75 \mathrm{~g} \text { cooked or less } \\
\text { between } 75 \text { and } 225 \mathrm{~g} \text { cooked } \\
225 \mathrm{~g} \text { cooked or more }\end{array}$ & $\begin{array}{l}1 \text { cooked potato (size of an } \\
\text { egg) }=50 \mathrm{~g} \\
1 \text { tablespoon of mashed potatoes } \\
\quad=50 \mathrm{~g}\end{array}$ \\
\hline
\end{tabular}




\begin{tabular}{|c|c|c|c|}
\hline Food groups & $\begin{array}{l}\text { How often does your child } \\
\text { consume the following products? }\end{array}$ & $\begin{array}{l}\text { and what is the average } \\
\text { portion per day? }\end{array}$ & Example portion sizes \\
\hline Raw vegetables & $\begin{array}{l}\text { never or less than once per month } \\
1-3 \text { days per month } \\
1 \text { day per week } \\
2-4 \text { days per week } \\
5-6 \text { days per week } \\
\text { every day }\end{array}$ & $\begin{array}{l}\circ 40 \mathrm{~g} \text { or less } \\
\circ \text { between } 40 \text { and } 120 \mathrm{~g} \\
120 \mathrm{~g} \text { or more }\end{array}$ & $\begin{array}{l}1 \text { tablespoon of carrots }=20 \mathrm{~g} \\
1 \text { tomato }=150 \mathrm{~g}\end{array}$ \\
\hline Prepared vegetables & $\begin{array}{l}\text { never or less than once per month } \\
1-3 \text { days per month } \\
1 \text { day per week } \\
2-4 \text { days per week } \\
5-6 \text { days per week } \\
\text { every day }\end{array}$ & $\begin{array}{l}\circ 60 \mathrm{~g} \text { or less } \\
\text { between } 60 \text { and } 180 \mathrm{~g} \\
180 \mathrm{~g} \text { or less }\end{array}$ & $\begin{array}{l}1 \text { tablespoon of prepared vegetables } \\
\quad=30 \mathrm{~g}\end{array}$ \\
\hline
\end{tabular}

Please indicate for the following questions the food product or food group your child consumes mostly

What kind of water does your child usually drink?

O tap water

$\bigcirc$ bottled water

not applicable (my child never drinks water)

If bottled water, which brand does your child usually drink?

What kind of fruit juice does your child usually drink?

$\bigcirc$ freshly squeezed fruit juice

$\bigcirc$ long-life fruit juice

$\bigcirc$ not applicable (my child never drinks fruit juice)

What kind of milk does your child usually drink?

O skimmed milk

o semi-skimmed milk

whole milk

not applicable (my child never drinks milk)

What kind of yoghurt does your child usually eat?

O skimmed yoghurt

o semi-skimmed yoghurt

$\bigcirc$ whole yoghurt

not applicable (my child never eats yoghurt)

What kind of fresh cheese does your child usually eat?

skimmed fresh cheese

$\bigcirc$ semi-skimmed fresh cheese

$\bigcirc$ whole fresh cheese

not applicable (my child never eats fresh cheese)

What kind of cheese spread/melted cheese does your child usually eat?

O skimmed cheese spread/melted cheese

$O$ semi-fat cheese spread/melted cheese

$\bigcirc$ fat cheese spread/melted cheese

not applicable (my child never eats cheese spread/melted cheese)
What kind of chocolate does your child usually eat?

pure or fondant chocolate

$\bigcirc$ milk chocolate

$\bigcirc$ white chocolate

not applicable (my child never eats chocolate)

What kind of chocolate sprinklers or chocolate flakes does your child usually eat?

pure or fondant chocolate sprinklers or flakes

milk chocolate sprinklers or flakes

$\bigcirc$ not applicable (my child never eats chocolate sprinklers or flakes)

What kind of chocolate spread does your child usually eat?

$\bigcirc$ pure or fondant chocolate spread

$O$ chocolate spread with nuts

$\bigcirc$ milk chocolate spread

not applicable (my child never eats chocolate spread)

What other kind of sweet spreads does your child usually eat?

$\bigcirc$ peanut butter

$\bigcirc$ maple syrup

$\bigcirc$ jam or marmalade

$\bigcirc$ honey

$\bigcirc$ other, please specify:

$\bigcirc$ not applicable (my child never eats other sweet spreads)

What kind of bread does your child usually eat?

wholemeal bread

$\bigcirc$ brown bread

$\bigcirc$ white bread

not applicable (my child never eats bread)

What kind of rice does your child usually eat?

$\bigcirc$ brown rice

$O$ white rice

not applicable (my child never eats rice) 
What kind of pasta does your child usually eat?

$\bigcirc$ wholemeal pasta

$\bigcirc$ white pasta

not applicable (my child never eats pasta)

What kind of fat spread does your child usually use on his/ her bread, rusk...?

$\bigcirc$ no-fat spread

O butter

○ semi-skimmed butter (e.g. Balade...)

$\bigcirc$ margarine, margarine product minarine

$\bigcirc$ other, please specify:

Does your child usually (at least once per week) consume food products that are enriched with calcium (e.g. soya drinks enriched with calcium, breakfast cereals enriched with calcium...)?

$\bigcirc$ yes

ก no

If yes, please specify: 